\title{
Anxiety, the other, and the ethics of desire
}

Daniel Wilson

Robertson, Brian. Lacanian antiphilosophy and the problem of anxiety: An uncanny little object. New York: Palgrave Macmillan, 2015.

Wolf, Bogdan. Anxiety between desire and the body: What Lacan says in seminar X. New York: Routledge, 2019.

Both Brian Robertson's Lacanian Antiphilosophy and the Problem of Anxiety and Bogdan Wolf's Anxiety Between Desire and the Body follow the broad contours of Lacan's 1962-1963 seminar on anxiety, working through Lacan's discussion of anxiety with respect to the question of the Other's desire, the function of fantasy to cover over anxiety, Lacan's critique of countertransference, and the forms of the object (a) that fall away in anxiety. Neither, however, is a book of pure exegesis. In Lacanian Antiphilosophy, a tension emerges between what Robertson describes as the phenomenological stakes of Lacan's seminar - "to come to a clearer phenomenological formulation of the problem"(2)-and the question of why Lacan, as a psychoanalyst, is interested in anxiety as something that does not mislead the subject. Whereas Robertson's book reads as a standard academic book, Wolf's Anxiety Between Desire and the Body is a much stranger work. While Wolf closely follows Lacan's seminar, and refers throughout to a variety of psychoanalytic thinkers, he does not use any direct citations. The subtitle of Wolf's book is "What Lacan Says in Seminar $X^{\prime}$, yet, perhaps because Wolf is speaking for Lacan, his exegesis often collapses into a poetic register that risks becoming an obstacle to transmission. Wolf writes, for instance, that "masochism appears from the start as a truly trans-structural issue and for this reason most 'human' as captures a cycle of life between spring and autumn during which the real nevertheless thwarts the beautiful image because the subject's position stretches between the Other as desiring, and therefore lacking, and the object a that modulates and shifts the premature appetite for the autumn of life or the delayed yearning of the spring. That's why Lacan left these variants in the hands of topology, and of the torus in particular"(89). 
Anxiety does not mislead, but where does it lead? Does anxiety maintain us, as Wolf seems to suggest, in the grip of a masochistic jouissance where the object that covers over the Other's lack always reveals itself as insufficient? Does psychoanalysis describe an impasse, or support an ethics of desire? In other words, what do psychoanalysis, and psychoanalytic experience, have to offer?

Robertson writes that his use of "anti," in the question of Lacanian antiphilosophy, should be read the way that "orthodox christians tend to read the 'anti' in Antichrist"(12)-as something that displaces the Christ. His discussion of antiphilosophy does not enter into or engage with Badiou's discussion of Lacan as an anti-philosopher. Robertson is rather interested in the way that Lacan engages with philosophy-especially through Kierkegaard and Sartre-by not mounting an "assault on established philosophical doctrines"(12) but by offering "something new and imperceptibly-but undeniably-different"(13). Lacan, in other words, is not arguing with Kierkegaard and Sartre, but using them to open up a space to talk about anxiety within psychoanalysis. In these terms Robertson argues that "we stand to gain nothing by thinking deeply about anxiety, that is, by isolating the phenomenon and taking it as the object of a direct and sustained philosophical investigation"(210). This is because to make anxiety into a concept would be to "defraud anxiety's lesson [...] of its dreadfully inarticulable certainty"(210). This, however, leads to a kind of paradoxical position in Robertson's book. Robertson writes of Lacan's "anticonceptual"(210) approach to anxiety, yet suggests that Lacan is too cold and intellectual. Robertson writes: "Lacan has often been heavily criticized by neglecting the life of affects and emotions in favor of a more cerebral, 'intellectualist' theory concerning the subject's submission to the symbolic order of language"(101). Robertson continues that "while criticism of this sort is in large part justified, especially insofar as Lacan's distrust of the subject's 'lived experience' is concerned, it nevertheless fails to take into account the refreshing, alternative approach that Lacan opens up, in the Anxiety Seminar, 
to the tortured link between anxiety and language"(101). A question thus emerges of the relationship between what anxiety leads to, beyond the signifier, and what Lacan privileges as lived experience. Part of what is at stake here has to do with the status of experience in psychoanalysis. It is through castration that the field of psychoanalytic experience opens up; without castration, without the transference, there is no psychoanalytic experience.

This reserve about entering into psychoanalytic experience emerges most strikingly in Robertson's discussions of the fetish and of the agalma, which Lacan theorizes as the object at stake in the transference. Lacan, Robertson writes, "relates erotic anxiety directly to a deep and inescapable sense of 'embarras' (or embarrassment) before the Other. What he has in mind is the agonizing experience, not of the humiliation we feel upon being rejected, but of not knowing where we fit into the Other's desire"(31). Turning to a reading of perversion and the fetish, Robertson observes that the fetish object appears at the place of this question about the Other's desire, providing a response to this question. As Robertson puts it "the object that causes sexual desire is the fetish"(39). Therefore, "the fact that a man can only achieve orgasm with a certain kind of woman, and not just with any woman, reveals that the question of his satisfaction (or the 'reduction of tension' that occurs in orgasm) hinges upon another, more important question, namely the question of the pleasure's significance"(88). This strikes me as an excellent description of a certain way that a man can protect himself from what is at work in a woman's body by taking her body, or a piece of it, mobilized by a fantasy, as the cause of his orgasm. However, the manner in which Robertson collapses this reading of the fetish with his reading of the agalma, the object that Lacan identifies in his seminar on the transference as what is at stake in the transference, functions to close off the possibility that the transference could lead to a change of position both with respect to the lack in the Other, and with respect to one's own desire. 
An agalma is a small statue that is placed in the chest of a larger statue. In the Symposium, Alcibiades compares Socrates to a statue of Silenus-an ugly old man-that has something precious hidden inside. Robertson writes that"[I]n Alcibiades's highly ambiguous encomium of Socrates, for example, he singles out an elusive object of treasure-or agalma-that lies hidden within Socrates's belly. Like many a fetishist, he claims that no one but he is even aware of the treasure's presence, let alone of its inestimable value. While everyone else rests content to praise Socrates for his wit, good humor, and keen dialectical prowess, only Alcibiades has a nose for the intoxicating musk of Socrates irresistible sex appeal"(41). Robertson focuses on "Socrates's embarras"(35) at finding himself "caught in the nightmarish situation of incarnating an erotic absolute for his former beloved"(35). Robertson then proposes that we can “imagine Alcibiades's hands transforming into the barbed pincers of Lacan's dreaded praying mantis"(35). In other words, Robertson imagines that Socrates is in the grip of a fantasy of being devoured by the Other, who is incarnated by Alcibiades.

The reason, however, that Lacan takes Socrates's attitude towards Alcibiades as a model for the transference, is because of Socrates's "refusal to enter into the game of love"(Sem. VIII, 153). Lacan writes that in the transference, "the analyst is situated in the position of he who contains agalma"(Sem. VIII, 193). Because the analyst refuses to enter into this game, the analysand has the opportunity to speak, and to discover that the other is not the object of desire. In response to Alcibiades' advances Socrates says: "Cultivate your soul." This means, Lacan translates for us: "Know that what you are pursuing is nothing other than what Plato will later turn into your soul-namely, your image. Realize that this object functions not as an aim but rather as a mortal cause, and grieve this object. It is merely your [own] image. Then you will know the pathway of your desire. For the only thing that I-Socrates, who knows nothing-know is the function of Eros"(NdP, 70). The fetish does not explain desire. The point is that in the transference, in the experience of analysis, one can grieve the agalma, grieve the fetish, and discover the path of desire. 
In "Introduction to the Names-of-the-Father," the first session of the aborted seminar that would have followed the seminar on anxiety, Lacan writes that "I confined my attention last year to the function of the object $a$ in fantasy"(59). Lacan writes that the "object $a$ is what fell away from the subject when anxious" and continues that "it is the same object that I depicted as the "cause of desire"'(58). Lacan writes that the "object $a$ takes the place, for the subject, of the anxiety that does not mislead"(58). If anxiety does not mislead, it is equally important to ask where anxiety leads, and how the falling away of the fetish, of the agalma, opens a pathway for desire. The psychoanalyst Willy Apollon writes that "the Lacanian clinic favors an ethics where savoir is substituted for the quest for a jouissance that the treatment experience reveals as lapsed and thus impossible"(140). Apollon continues that analysis "is predicated on this failing of jouissance, that lack that pierces a hole in the chain of signifiers and that is signified in the object which Lacan calls object $a^{\prime \prime}(140)$. The experience of this failure at the level of the signifier, that there is something at stake in experience that goes beyond the signifier, introduces the subject to "the ethical requirement of a truth that is incommensurable with the knowledge of science or psychology"(140). This has the consequence that "the false need of belonging within the stakes of ego identifications justify themselves, disappears with the return and recognition of a desire bearing its own markers with no other regard for the demands of the Other than the symbolic limits of social or citizen coexistence"(140). It is only in taking the side of that which insists in experience, and which reveals the hole in the field of the signifier, that desire appears in the place of what is missing from language. In these terms, anxiety leads from a fantasy that maintains the Other, to a responsibility for a desire that has no relationship to the demands of the Other.

In a certain sense, Wolf takes the stakes of castration more seriously than Robertson. Wolf writes that in the Anxiety Seminar "[f]antasy [...] serves to protect the neurotic from anxiety-to keep anxiety at a distance and under control"(61). However, rather than 
opening to the possibility of the traversal of the fantasy that reveals the stakes of desire beyond the Other's demand, Wolf focuses on the way that castration functions as a kind of bedrock to an economy of pleasure. Throughout Anxiety Between Desire and the Body Wolf returns to the relationship of the detumescence of the organ to castration. Wolf argues that the orgasm covers over an anxiety about what the Other wants, an anxiety that is "a moment captured by the obsessional subject when during the satisfactory sexual life he has with his partner he suddenly becomes concerned whether he is going to run out of semen"(146). After the orgasm, when the penis becomes flaccid, there is an experience of castration - the falling away of the fantasy that protected against the Other's demand-and this castration brings a jouissance with it. Wolf writes that "the real contraction of the penis appears now as a new mark of castration"(128). This is "why the orgasm is sometimes called "a little death" because the subject dies in it at the moment of the cut. For the man, then, jouissance of the body is experienced at the very instant of castration cutting in, so to speak, the erectile happiness and causing detumescence"(122). Wolf writes: "Jouissance can only be achieved through castration. Jouissance at stake here is the bodily jouissance and therefore connected to orgasm"(122).

In his seminar on anxiety, however, Lacan goes out of his way to avoid this kind of misunderstanding. Lacan remarks at his astonishment at overhearing "two people whom I believe l've trained particularly well" wondering if the "satisfaction" of the orgasm is a matter "of jouissance"(261). Lacan's response is unambiguous: "In no way did I say that the satisfaction of orgasm was to be identified with [...] the locus of jouissance. It seems wry to underline the trifling satisfaction, albeit sufficient, that is brought by orgasm"(262). Lacan continues that "if this demand for death is what gets satisfied [in an orgasm], well, good gracious, it's lightly satisfied, because one gets off lightly"(263). The fact that, for Wolf, a man's only access to jouissance comes in the falling away of the penis after an orgasm keeps a man trapped within the field of satisfaction, the beyond of the pleasure principle-the death drive-reduced to a limit that keeps one within the scene of pleasure. 
A curiosity of Wolf's book is that it has no direct citations of Lacan nor of any other authors. One of the few evocations of the letter of Lacan's text comes in the opening pages of his book, where a misreading of Lacan's discussion of the Golden Number underlines this confusion between pleasure, and what goes beyond pleasure. Wolf writes that it is important to distinguish between "the object cause and the object of desire"(12). This is because "[w]hat causes my desire is not its object. I may want different things in life, travel to all sorts of beautiful places but they are not the cause of my desire"(12). Wolf continues:

Already in Seminar X, Lacan insists on the strictly indeterminable character between the object of desire and the cause. Do they ever intersect, overlap? In his Seminar "RSI", Lacan refers this impossibility to the Golden Number. This number can be formulated as:

$$
1 / \mathrm{a}=1+\mathrm{a}
$$

There is no one and the same value of "a" in both cases except for 0 . And this is where the difference between the analyst's anxiety and desire can be situated. The Lacanian object little $a$, the little real, can have different functions but only one value that in the field of algebra is correlative to zero. (12)

This astonishing mistake with grade school level math risks calling into question the aim and scope of psychoanalysis as such. A number divided by zero is undefined, whereas $1+$ $0=1$. Zero is not a possible solution to "a" in the above formula. In the formula "a" does indeed have a value, just not a rational value. The golden number is irrational: it is something that is approached, but which can never be written out. The golden number describes the forms of nautilus shells, spiral galaxies, pine cones, and the array of sunflower seeds. In a more properly psychoanalytically register, it determines a form because it doesn't stop not being written. Part of what Lacan seems to be pointing at with 
the example of the golden mean is the fact that the object-cause of desire is missing from reality. There is a real loss that psychoanalysis insists upon; there is a jouissance that is impossible, that is lost because of the fact that we speak. The object $a$, as what falls away, describes the logic of what is missing from reality, and thus traces the pathway of desire. A knowledge-what Apollon calls a savoir-about this lack opens to a desire beyond the Other, beyond what is given.

Lacan's evocation of the golden number functions as an affirmation of an essential dimension of human experience that opens up through castration, that follows the path of desire beyond the discovery that there is nothing given in reality that could be an object of human desire. The jazz saxophonist Sonny Rollins, in a recent interview with David Marchese, expresses this in brutal terms. "In a sense," he says, "I hate this world. It's so inconsequential. Sure, there might be a good movie or this or that but we don't have time for it. Instead we have to try to get some wisdom." When Marchese asks Rollins if his music is also inconsequential, Rollins responds that “I didn't say everything was inconsequential. I can listen to some beautiful music, I can see a beautiful painting, and I wouldn't dare to say they're inconsequential. But the majority of what you see out here is inconsequential. Eating ice cream, wanting to have sex with some broad - Oh boy, she's beautiful and all that stuff - the seven deadly sins." Ice cream and orgasms cover over the lack in the Other, as if the human could find a limit in the satisfaction of the organism. Castration is not just the experience that inconsequential satisfactions do not fill the void, but is an opening beyond a fantasy that holds the being in the grip of the Other's demand, to a desire to sustain something consequential in a world that one has every reason to hate. It is, after all, only when psychoanalysis lets us speak of something beyond what is given in reality, beyond what is offered in psychiatry or the sciences, that its offer is credible. 


\section{References}

Apollon, Willy. "From Symptom to Fantasy." After Lacan: Clinical Practice and the Subject of the Unconscious. Edited by Hughes and Malone. Albany: SUNY Press, 2002, pp. 127-140

Lacan, Jacques. "Introduction to the Names-of-the-Father." On the Names-of-the-Father. Trans. Bruce Fink. Malden: Polity, 2013.

--- The Seminar of Jacques Lacan, Book VIII : Transference. Ed. Jacques-Alain Miller, Trans. Bruce Fink. Malden : Polity Press, 2015.

--- The Seminar of Jacques Lacan, Book X : Anxiety. Ed. Jacques-Alain Miller, Trans. A.R. Price. Malden : Polity Press, 2014.

David Marchese. "The Jazz Icon Sonny Rollins Knows Life Is a Solo Trip." New York Times Magazine. 24 Feb., 2020, https://www.nytimes.com/interactive/2020/02/24/magazine/sonny-rollinsinterview.html. Accessed 20 March 2020.

Robertson, Brian. Lacanian Antiphilosophy and the Problem of Anxiety: An Uncanny Little Object. New York: Palgrave Macmillan, 2015.

Wolf, Bogdan. Anxiety Between Desire and the Body: What Lacan Says in Seminar X. New York: Routledge, 2019. 